\title{
Highlight on Advances in Proteolysis Research
}

This Highlight Issue emanates from the $5^{\text {th }}$ General Meeting of the International Proteolysis Society (IPS2007; http://www.ips2007patras.gr), held October 20-24, 2007, at the Conference and Cultural Center of the University of Patras, Greece, directly after the $2^{\text {nd }}$ International Symposium on Kallikreins (ISK2007, October 16-18, 2007) on Santorini Island, Greece.

The local committee headed by Georgia Sotiropoulou (Department of Pharmacy, University of Patras) organized an exciting conference with 520 international participants. Pre-meeting events included postgraduate courses offering lectures and hands-on training to 60 young scientists on the topics (1) proteomics: methodologies and applications, (2) bioinformatics: computational methods in biological data mining, and (3) enzyme mechanisms and kinetics.

The IPS2007 meeting highlighted state-of-the-art research on proteolysis, including exciting advances in understanding structure, function and regulation of proteases and protease inhibitors in animals, plants and pathogens, as well as the mechanisms by which proteases, receptors and regulatory molecules contribute to homeostasis, aging and disease. Mainstream technologies were presented that permit a global view of the effects of proteases, e.g., proteomics, degradomics, imaging, innovative chemical tools and protease-based platforms for drug development. Plenary sessions, lunch workshops and 330 poster presentations covered the topics proteolysis in physiological processes and disease mechanisms; insights into protease specificity, mechanisms and regulation; intracellular and extracellular shedding of membrane proteins - signaling pathways; intramembrane proteolysis in health and disease; processing and degradation - ubiquitin and the proteasome; inflammation and cell death cascades; pathogen invasion and host defense; proteolytic pathways in the tumor microenvironment; protective effects of proteases and inhibitors on tumor progression; degradomics - protease proteomics and genomics; imaging and in vivo probes new technologies; pathology and drug discovery - therapeutic advances in protease inhibition and modulation; biotechnology of proteases and inhibitors - transgenic animals and plants.

The opening keynote lecture of Nobel Laureate Aaron Ciechanover (Technion-Israel Institute of Technology, Israel) was entitled 'The ubiquitin proteolytic system: from basic mechanisms through human diseases and onto drug targeting', and the meeting was concluded with a closing lecture by Guy Salvesen (Burnham Institute for Medical Research, USA) on 'Lessons learned about proteases by studying apoptosis'. Plenary lectures were given e.g., on 'Proteases and aging: the nuclear envelope connection' by Carlos Lopez-Otin (University of Oviedo,
Spain), 'Understanding how Granzymes get into cells: the structure of a MACPF/Perforin-like protein' by James Whisstock (Monash University, Australia), 'Cellular recycle system - molecular dissection of membrane dynamics during autophagy' by Yoshinori Ohsumi (National Institute for Basic Biology, Okazaki, Japan), and on 'Regulated intramembrane proteolysis in apoptosis and Alzheimer's disease' by Bart De Strooper (VIB, Centre for Human Genetics, Belgium).

The IPS has been awarding Honorary Lifetime Memberships to scientists with outstanding credentials (Table 1). In Patras, these prestigious memberships were presented to Judith Bond (Pennsylvania State University, Hershey, PA, USA) and Ben Dunn (University of Florida, Gainesville, FL, USA) for their outstanding engagement in the proteolysis field. In addition, the Commemorative Gold Medal of the E.K. Frey-E. Werle Foundation of the Henning L. Voigt Family was presented by its Governor Hans Fritz to Eleftherios Diamandis (Mount Sinai Hospital and University of Toronto, Canada) in recognition of his seminal contributions to the identification and characterization of the expanded gene locus of kallikrein-related peptidases and their significance as cancer biomarkers. The Junior Investigator Prize (sponsored by Verisfield UK Ltd) was awarded to Mekdes Debela (Max Planck Institute for Biochemistry, Martinsried, Germany) and the Biochemical Journal Poster Prize (sponsored by The Biochemical Journal) to Elizabeth Ponder (Stanford University, USA).

IPS meetings have their roots in a long tradition. As early as 1970, Hans Fritz and Harald Tschesche, as well as Alan Barrett and John Dingle organized meetings in Munich and Cambridge, respectively (Table 2). Subsequently, Horst Hanson held the first symposium on 'Intracellular Protein Catabolism' in 1973 at the Martin Luther University at Halle (former German Democratic Republic, GDR). Stimulated by the success, Vito Turk, who could freely travel from Yugoslavia to East Germany, organized the $2^{\text {nd }}$ symposium in Ljubljana (Slovenia, former Yugoslavia). The East German scientists with Horst Hanson, Peter Bohley, Heidrun Kirschke, Harald Aurich and Bernd Wiederanders continued this series of meetings in 1977 , 1981 and 1986. They attracted and interested an increasing number of scientists from outside the GDR so that

Table 1 Honorary Lifetime Memberships presented on occasion of the biannual IPS General Meetings.

IPS2001 (Freising near Munich, Germany) to Nobuhiko Katunuma and Hans Fritz

IPS2003 (Nagoya, Japan) to Koichi Suzuki and Vito Turk IPS2005 (Quebec City, Canada) to Jim Travis and Wolfram Bode

IPS2007 (Patras, Greece) to Judith Bond and Ben Dunn 
Table 2 The IPS Conferences and their predecessors.

\begin{tabular}{|c|c|c|}
\hline \multicolumn{3}{|c|}{ Early meetings } \\
\hline 1970 & Symposium on 'Tissue Proteinases', Cambridge, UK ${ }^{1}$ & Barrett and Dingle \\
\hline 1970 & Conference on 'Proteinase Inhibitors', Munich, FRG² & Fritz and Tschesche \\
\hline \multicolumn{3}{|c|}{ Symposia on Intracellular Protein Catabolism } \\
\hline 1973 & $1^{\text {st }}$ Symposium at Castle Reinhardsbrunn, Halle, GDR ${ }^{3}$ & Hanson and Bohley \\
\hline 1975 & $2^{\text {nd }}$ Symposium in the Josef Stefan Institute, Ljubljana, Yu ${ }^{4}$ & Turk and Marks \\
\hline 1977 & $3^{\text {rd }}$ Symposium at Castle Reinhardsbrunn, Halle, GDR ${ }^{5}$ & Hanson and Ansorge \\
\hline 1981 & $4^{\text {th }}$ Symposium at Castle Reinhardsbrunn, Halle, GDR ${ }^{6}$ & Aurich and Wiederanders (ECOP) \\
\hline 1984 & $5^{\text {th }}$ Symposium in the Airlie Conference Center, Virginia, USA ${ }^{7}$ & Khairalla, Bird, Bond (ACOP) \\
\hline 1986 & $6^{\text {th }}$ Symposium in Büchenberg, Halle, GDR ${ }^{8}$ & Aurich and Kirschke (ICOP) \\
\hline \multicolumn{3}{|c|}{ Conferences/Symposia on Proteolysis (ICOP Meetings) } \\
\hline 1988 & $7^{\text {th }}$ Symposium on 'Intracellular Proteolysis' in Shimoda, Japan ${ }^{9}$ & Katunuma and Kominami \\
\hline 1990 & $\begin{array}{l}8^{\text {th }} \text { Symposium on 'Proteolysis' (extra/intracellular and protease inhibitors) } \\
\text { in Wildbad Kreuth, Germany }{ }^{10}\end{array}$ & Fritz and Jochum \\
\hline 1992 & $\begin{array}{l}9^{\text {th }} \text { Symposium on 'Proteolysis and Protein Turnover' in Williamsburg, } \\
\text { Virginia, USA }{ }^{11}\end{array}$ & Bond and Sloane \\
\hline 1994 & $10^{\text {th }}$ Symposium on 'Intracellular Protein Catabolism' in Tokyo, Japan ${ }^{12}$ & Suzuki \\
\hline 1996 & $11^{\text {th }}$ Symposium on 'Proteolysis in Cell Functions' in Turku, Finland ${ }^{13}$ & Hopsu-Havu and Kirschke \\
\hline \multicolumn{3}{|c|}{ General Meetings of the International Proteolysis Society (IPS) } \\
\hline 1999 & $1^{\text {st }}$ IPS Conference on Mackinac Island, Michigan, USA & Sloane and Salvesen \\
\hline 2001 & $\begin{array}{l}2^{\text {nd }} \text { IPS Conference in Freising near Munich, Germany } \\
\text { Proceedings in Biol. Chem. 383, 1029-1314 (2002) }\end{array}$ & Jochum, Fritz, Bode, Sommerhoff \\
\hline 2003 & $\begin{array}{l}\text { 3rd IPS Conference in Nagoya, Japan } \\
\text { Proceedings in Biol. Chem. 385, 447-568 (2004) }\end{array}$ & Mizutani \\
\hline 2005 & $\begin{array}{l}4^{\text {th }} \text { IPS Conference in Quebec City, Canada } \\
\text { Proceedings in Biol. Chem. 387, 825-1003 and 1005-1146 (2006) }\end{array}$ & Tremblay \\
\hline 2007 & $\begin{array}{l}5^{\text {th }} \text { IPS Conference in Patras, Greece } \\
\text { Proceedings in Biol. Chem. 389, 971-1142 (2008) }\end{array}$ & Sotiropoulou \\
\hline
\end{tabular}

For proceedings see:

${ }^{1}$ Barrett, A.J. and Dingle, J.T., eds. (1971). Tissue proteinases. Proceedings of the Royal Society Wates Symposium, held at the Strangeways Research Laboratory, Cambridge 1970 (Amsterdam and London: North-Holland Publishing Co., New York: American Elsevier Publishing Co.).

${ }^{2}$ Fritz, H. and Tschesche, H., eds. (1971). Proceedings of the International Research Conference on Proteinase Inhibitors, Munich, 1970 (Berlin, New York: Walter de Gruyter).

${ }^{3}$ Hanson, H. and Bohley, P., eds. (1974). Intracellular Protein Catabolism. Proceedings of the Symposium, Reinhardsbrunn Castle 1973 (Halle/Saale, Germany: Wissenschaftliche Beiträge der Martin-Luther-Universität Halle-Wittenberg 1974/6, R 27). ${ }^{4}$ Turk, V., Marks, N., Barrett, A.J., and Woessner, J.F., eds. (1977). Intracellular Protein Catabolism II. Proceedings of the $2^{\text {nd }}$ International Symposium, Ljubljana 1975 (New York and London: Plenum Press).

${ }_{5}^{5}$ Hanson, H., Ansorge, S., and Bohley, P., eds. (1977). Intracellular Protein Catabolism III. Proceedings of the $3^{\text {rd }}$ Symposium, Schloß Reinhardsbrunn 1977. Acta Biol. Med. Germ. 36, 1505-1968.

${ }^{6}$ Aurich, H., Langner, J., and Wiederanders, B., eds. (1981/1982). Intracellular Protein Catabolism IV. Proceedings of the $4^{\text {th }}$ Symposium, Schloß Reinhardsbrunn 1981. Acta Biol. Med. Germ. 40, 1209-1658 and 41, 31-135.

${ }^{7}$ Khairallah, E.A., Bond, J.S., and Bird, J.W.C., eds. (1985). Intracellular Protein Catabolism. Proceedings of the $5^{\text {th }}$ International Symposium, held at the Airlie Conference Center 1984 (New York: Alan R. Liss).

${ }^{8}$ Aurich, H., Kirschke, H., and Wiederanders, B., eds. (1986). Intracellular Protein Catabolism VI. Proceedings of the 6 $6^{\text {th }}$ Symposium, Haus Büchenberg, Wernigerode 1986. Biomed. Biochim. Acta 45, 1359-1663.

${ }^{9}$ Katunuma, N. and Kominami, E., eds. (1989). Intracellular Proteolysis. Mechanisms and Regulations. Proceedings of the $7^{\text {th }}$ ICOP meeting, Shimoda 1988 (Tokyo, Japan: Springer Verlag/Japan Soc. Press).

${ }^{10}$ Kirschke, H., Fritz, H., Holzer, H., Jochum, J., and Wolf, D.H., eds. (1991). $8^{\text {th }}$ Conference on Proteolysis. Biomed. Biochim. Acta 50, 318-828.

${ }^{11}$ Bond, J. and Barrett, A.J., eds. (1993). Proteolysis and Protein Turnover (London and Chapel Hill: Portland Press).

${ }^{12}$ Suzuki, K. and Bond, J.S., eds. (1996). Intracellular Protein Catabolism (New York: Plenum Press).

${ }^{13}$ Hopsu-Havu, V.K., Jarvinen, M., and Kirschke, H., eds. (1997). Proteolysis in Cell Functions (Amsterdam, The Netherlands: IOS Press).

Proceedings published as monographs are available from one of the authors (sommerhoff@lmu.de) on request.

the $5^{\text {th }}$ meeting of this series was held in Airlie (Virginia, USA) by Edward Khairallah, Judith Bond and John Bird, and the $7^{\text {th }}$ symposium in Shimoda near Tokushima (Japan) by Nobuhiko Katunuma and Eiki Kominami.

To foster communications among scientists working on proteases, their inhibitors and protein turnover the European Committee on Proteolysis (ECOP) followed by the American (ACOP) and Japanese (JCOP) were founded in the early 1980 s. On the occasion of the $5^{\text {th }}$ Symposium in Airlie in 1984, these committees were united into the International Committee on Proteolysis (ICOP). A particularly stimulating ICOP meeting took place in Southern Bavaria (Wildbad Kreuth near Munich) in 1990, i.e., shortly after the unification of Germany when scientists from East Germany and other Eastern countries could freely travel to Western Europe for the first time. The newly acquired freedom to attend proteolysis meetings worldwide caused considerable euphoria among the colleagues from the Russian sphere of influence. As a service to the community, the ICOP newsletter was 
established which was distributed between 1990 and 1996 by committee members to approximately 400 colleagues worldwide with information, e.g., on hot topics, meetings, book announcements and open positions.

A crucial step forward in the proteolysis field was taken with the establishment of the International Proteolysis Society (IPS) on Mackinac Island in 1999 with Bonnie Sloane as founding chair, marking the transition to a formal society with an elected board of officers. One of the missions of the IPS (http://www.protease.org) is to hold International General Meetings (Table 2). Primarily due to the initiatives of Hans Fritz, who served as Executive Editor of Biological Chemistry in the proteolysis field since 1993, a tradition started in 2002 with an Editorial written by Bonnie Sloane, the founding chair of the IPS, and her successor, Jennifer Rivett, introducing the first IPS Highlight Issue in this journal. Biological Chemistry thus has become the de facto International Journal of the IPS. After having served as Editorial Board member for more than 20 years and as Executive Editor for 15 years, Hans Fritz is now retiring. Obviously, Hans would very much like to see the bonds between Biological Chemistry and the IPS strengthen and for Biological Chemistry to become the official Journal of the IPS and its future Conferences.

The upcoming $6^{\text {th }}$ General Meeting of the IPS will be organized in Surfers Paradise, Australia, October 26-30, 2009 by James Whisstock, Rob Pike and Phil Bird. We are looking forward to seeing all of you 'down under', and hopefully those interested in kallikrein-related peptidases also at the preceding $3^{\text {rd }}$ International Kallikrein Symposium in Munich (September 16-19, 2009). Further information on the IPS and the Conferences are available on their homepages http://www.protease.org, http:// www.IPS2009.org and http://www.IKS2009.org.

\section{Georgia Sotiropoulou}

Department of Pharmacy, University of Patras,

GR-26500 Rion-Patras, Greece

e-mail: gdsotiro@upatras.gr

\section{Christian P. Sommerhoff}

Division of Clinical Chemistry and Clinical Biochemistry, Surgical Department, Ludwig Maximilians University,

D-80336 Munich, Germany

e-mail: sommerhoff@Imu.de 